\title{
OVERSETTEREN I ET MULTIMEDIALT NETTVERK. OM DEN POLSKE OVERSETTELSEN AV JULIE ANDEMS SKAM-MANUSER
}

\author{
KAROLINA DROZDOWSKA
}

\begin{abstract}
This article presents a case study of the translation process of Julie Andem's SKAM scenarios (originally published in Norwegian in 2018) into Polish, focusing upon the challenges a translator has to face when confronted with a very specific, unedited text and different multimedial actors involved in the said process. It analyzes the question of how their existence and activity in the network influences the translator's roles and strategies. SKAM (broadcast from 2015 to 2017), originally never meant to be distributed outside of Norway, gained massive popularity and became a global phenomenon, with large groups of fans all around the world. The article gives a brief presentation of the series itself and moves on to describe the books' unique form, before outlining the theoretical background for the case study: the Actor-Network Theory (ANT). The article analyzes the translator in confrontation with three different groups of actors, describing how they influence the process, thus forcing the translator to adapt to new roles and take on new tasks. This text may also serve as a starting point for a broader reflection upon the place of a literary translator in a changing, globalized cultural reality.
\end{abstract}

Keywords: SKAM, Julie Andem, literary translation, Actor-Network Theory

\section{Den uoffisielle eksportvaren}

I sin forelesning under MediaMorfosis-konferansen i Buenos Aires i september 2017 innrømte Julie Andem og Mari Magnus at SKAMs store internasjonale suksess var en overraskelse for alle som arbeidet med den norske nettbaserte dramaserien. Den 43 episoder og fire sesonger lange historien som ble endelig avsluttet forsommeren 2017, er, per i dag, kjent i omtrent hele verden, med egne versjoner i hele sju land. ${ }^{1}$ Christopher Pahle,

1 DRUCK (Tyskland), Skam Austin (USA), Skam España, Skam France, Skam Italia, Skam NL samt WtFOCK (Belgia). 
i sin artikkel i Dagbladet fra 2018, kaller ungdomsserien "Norges fremste eksportvare siden bindersen".

Den globale SKAM-manien kan virke overraskende særlig når man tar med i betraktningen, som forskerne Dugan og Dahl påpeker i en artikkel fra 2019, at serien ikke var laget med tanke på internasjonal distribusjon (7). "Ikke tilgjengelig utenfor Norge" lyder beskjeden man får opp på skjermen når man besøker SKAMs offisielle nettside skam.p3.no og forsøker å se en av seriens episoder eller filmutsnitt med en ikke-norsk IP-adresse. Løsningen med geoblokkering av innholdet for utenlandske brukere ble innført i januar 2017 og var, ifølge nyhetsbyrået NTB, et resultat av krav fra musikkforlagene. "Ifølge IFPI Norge har ikke NRK betalt for internasjonale visningsrettigheter til musikken deres", lød den offisielle pressemeldingen. Dette hindret imidlertid ikke den internasjonale fandommen fra å fortsette å se sin yndlingsserie. Råd om hvordan man skal jukse med IP-adresse for å få tilgang til det blokkerte innholdet begynte fort å dukke opp på internett, man kunne til og med lese en hel artikkel med nøyaktige instrukser på nettsidene til den danske tabloidavisen Se og hør (Minana 2017). Episodene begynte dessuten å legges ut på ikke-offisielle nettsider med streamingtjenester SKAM-fans sendte hverandre lenker til. Å se på den norske serien utenfor Norge ble dermed til noe halvveis ulovlig, nesten hemmelig, noe bare "de innvidde" hadde tilgang til. Dette førte utvilsomt til enda sterkere integrering av fandom-gruppene verden over. ${ }^{2}$

Det råder ingen tvil om at SKAMs enorme popularitet bidro til større interesse for norsk språk og kultur utenfor landets grenser. ${ }^{3}$ Jean-Baptiste Coursaud, en skjønnlitterær oversetter fra norsk til fransk bosatt i Berlin, påpeker i et intervju for NRK radio at skandinavistikk - instituttene ved tyske universiteter ser en betydelig økning i antall nye studenter som ønsker å studere norsk, nettopp på grunn av SKAM. Coursaud ser dette som et positivt fenomen og mener at "en større kunstnerisk interesse" for landet hvis litteratur han er oversetter og formidler av, alltid er noe å glede seg over, uansett hvor denne interessen stammer fra.

SKAM-manien har også spredt seg til Tysklands naboland, Polen. Siden serien ikke er offisielt tilgjengelig på noen plattformer, er det vanskelig å anslå hvor stor den polske fandommen egentlig er, men når man søker på "Skam Polska” [“Skam Polen”] på Facebook, finner man tre grupper: SKAM Polska (29 000 medlemmer), SKAM POLAND (52 000 medlemmer) og SKAM POLSKA GRUPA FANÓW SERIALU [Skam Polen-gruppen for seriens fans] (12 000 medlemmer), i tillegg til én profil man kan "like", SKAM Polska (46 000 likes). Selv om det er umulig å si noe konkret om den polske fandommens størrelse ut fra disse tallene (den samme personen kan være medlem av alle de ovennevnte gruppene), kan man med ganske stor trygghet anslå at det er snakk om titalls tusen polske seere og tilhengere av den norske ungdomsserien. Denne forholdsvis store gruppen har tilgang til SKAMs episoder hovedsakelig gjennom streamingsplattformen cda.pl, der alle av seriens fire sesonger kan sees gratis. En av de ovennevnte Facebook-gruppene, SKAM POLAND, tilbyr sine medlemmer nettlenker som ikke bare fører til sidene med den norske serien, men også til episoder av de fleste av de utenlandske SKAM-versjonene, uten å bry seg noe særlig om spørsmålet om internasjonale visningsrettigheter. På platt-

Flere norske medievitere har skrevet om seriens fenomen, se f.eks. Rettberg 2017 eller Sundet 2019. Noe som forresten er et velkjent fenomen, dokumentert i forbindelse med andre nordiske serier, bl.a. danske Forbrydelsen og Borgen, se f.eks. Philipsen og Hochscherf 2016. 
formen finner man episodene med polsk teksting - laget av fandommen selv, i mange tilfeller med den engelske versjonen som utgangspunkt, noe jeg skal komme tilbake til.

Den store interessen for SKAM gjenspeiles også i den vitenskapelige diskursen innen polsk skandinavistikk. Maja Chacińska, en av de få polske medievitere som forsker på Skandinavia, har viet et eget underkapittel til fenomenet SKAM i sin bok fra 2018. Ved Universitetet i Gdańsk, den eneste vitenskapelige institusjon i Polen hvor man kan velge skandinaviske medier som spesialiseringsområde, ble det i årene 2017-2019 skrevet to masteroppgaver og fire bacheloroppgaver med den norske serien som prosjektenes utgangspunkt. ${ }^{4}$

Det var kanskje nettopp denne økende interessen for SKAM blant ungdommene, studentene og Facebook-brugerne som førte til at forlaget Rebis bestemte seg for å kjøpe rettighetene til Julie Andems bøker og publisere dem på det polske markedet.

\section{Råmanus}

Dreiebøkene ble opprinnelig utgitt på norsk i 2018 av Armada Forlag (opprettet samme år), et imprint av Strawberry Publishing Norge. På nettsidene til forlaget kan man lese at "på Armada utgir vi norsk og oversatt skjønnlitteratur". SKAM-manusene var noen av de første bøkene publisert med Armadas logo. Det er til sammen fire bind (hvert bind tilsvarer én av seriens sesonger), med henholdsvis gult, hvitt, grått og sort omslag, alle designet av det prestisjefulle byrået Snøhetta. Reklameteksten på forlagets nettside lyder: "Denne boken inneholder scener som aldri ble spilt inn, replikker som senere ble klippet bort, samt Julie Andems kommentarer og tankekart. Dette er manusene til SKAM, akkurat slik de ble skrevet”. På forsiden til hver av bøkene, i tillegg til seriens tittel og sesongens nummer samt navnet på hovedpersonen (henholdsvis: Eva, Noora, Isak og Sana), har ordet "Råmanus" blitt inkludert som en slags undertittel, for å antyde at det leseren holder i hendene er nøyaktig den samme teksten som ble skrevet at Julie Andem, uten rettelser, sløyfninger eller noen som helst form for redigering.

Det at dreiebøkene ikke har undergått noen som helst form for faglig eller språklig redigering, er også understreket i bøkenes innmat. "Dette er manusene til SKAM sesong 1 slik de ble skrevet forsommeren og høsten 2015”, står det i det første bindet, rett etter prologen (Andem SKAM 1 6). Identiske opplysninger (med andre datoer) finnes også i de tre øvrige bind. Bøkene utgitt av Armada inneholder de fleste scenene man faktisk kan se i selve serien, i tillegg til noen ekstra elementer som ikke har blitt spilt inn. I tillegg er det noen sekvenser i manusene som avviker betydelig fra det man kan se på skjermen. Noen deler av teksten er markert med grå skrift, uten at det blir forklart hva det betyr noe sted (antakelig er det scener som Andem mente kanskje skulle slettes/bearbeides).

Den manglende redaksjonsprosessen er noe selv en uerfaren leser fort legger merke til. Manusene virker, på mange måter, "ufullstendige". Noen scener er ikke skrevet ferdig og teksten inneholder små "beskjeder" fra Andem til produksjonsteamet eller direkte til

4 Temaene for oppgavene var: fremstilling av kvinner i serien (Berbeć 2018), norsk nasjonal identitet (Ćwikowska 2017), en komparativ analyse av den norske SKAM og den amerikanske Skam Austin (Drzycimska 2019), sosiale spørsmål framstilt i serien (Kaczmarek 2017), SKAMs mottakelse i Danmark (Turzyńska 2017) og diskursanalyse av religion i serien (Włodarczyk 2018). 
skuespillerne. I sesong 1, for eksempel, i en scene hvor Jonas og Isak forteller Eva om en konsert de skal på, finner vi følgende dialog:

ISAK: Vi har billetter til FYLL INN KONSERT SOM ER I OSLO DEN DAGEN, SOM DE VILLE GÅTT PA (17)

I en scenebeskrivelse til et av klippene i episode 2 av samme sesong leser vi:

ANNET: Spør Marlon [dvs. Marlon Langeland, skuespilleren som spiller Jonas - min kommentar] hvilke sanger han kan på gitar, og spor hva som er en soperlåt og om han kan lære seg den. (30)

I manusene til sesong 2 finnes det bl.a. en scene hvor karakterene Noora og William tuller med hverandre. Her kan man finne følgende instrukser:

WILLIAM: Nei, vestkantklisjeer er sånn her: WILLIAM gjør parodi på en vestkantklisje. (Thomas [dvs. Thomas Hayes som spiller William - min kommentar]: Jeg dreit i å skrive ut denne som vi snakka om, bare gjør det greiene du gjorde på set her om dagen)

Av og til er manusene supplert med notater som kan antyde at Andem begynte å bli lei eller frustrert mens hun skrev dem. En av scenene i episode 11, sesong 1, begynner med en slik introduksjon:

EVA og NOORA går bortover korridoren på skolen. Eller sitter de et sted. Så man slipper blokkinga? Jeg vet da faen jeg. Skal jeg tenke på det også nå. Jeg finner ut av det. De snakker om noe og. Jævlig bra at dette er siste episode for nå er det heeelt tomt i nøtta. Uansett. (182)

Andre ganger forsøker manusforfatteren å overtale produksjonsteamet sitt om at det hun har skrevet er meget viktig og absolutt bør tas opp (noe som antyder at lengden på episodene kunne vært et problem under produksjonsprosessen). I sesong 3 som konsentrerer seg om Isak og hans kjæreste Even, rett før sceneinstruksene til det første klippet av episode 8, hvor det blir avslørt at en av guttene sliter med en psykiatrisk diagnose, skriver Andem:

\section{(Kjære teamet. Her kommer ep 8.}

Pliis pliiis pliis ikke hat meg. Jeg vet godt at det er for mye, men ok, hør da. Verden trenger dette. Og jeg lover å ta ep 9 veldig ned. OG det kommer til å gå fint hvis vi klarer å løse lys veldig enkelt, Se for oss fredagsfilmen nesten dokumentarisk. Se på det da i hvertfall? Ok. Unnskyld.) (128).

Disse beskjedene, kommentarene og utelatelsene er imidlertid ikke de eneste tegnene på manusenes "uferdighet". Ikke alle scener har titler - noen markeres kun med "XXXX" eller “TITTEL”, og flere steder står det “(STRYKES?)” før bestemte scener eller deler av 
dem. I tillegg er det et ganske stort antall skrive- og trykkfeil i bøkene, for eksempel navnet Stella McCartney blir stavet "Mccarty" i sesong 1 (90) og navnet til en av karakterene, Mahdi, blir gjentatte ganger skrevet som "Madhi" i sesong 3 og 4.

At et forlag publiserer fire bøker i denne formen, uten noen som helst form for redaksjon, språkvask eller korrektur, må ha en bestemt årsak og et bestemt mål. I dette tilfellet kan man konkludere med at målet var størst mulig autentisitet som skulle tiltrekke potensielle lesere, dvs. seriens fans. Det er vanskelig å forestille seg at Andems "råmanus" er ment for andre enn dem som har sett SKAM og kjenner serien veldig godt. Fandommen kan uten tvil finne flere "godbiter" i dreiebøkene publisert av Armada: hver bok er utstyrt med en for- og baksats med Andems håndtegnede "tankekart" (noen i sort-hvitt, noen i farger), med ideer for sesongene. I tillegg til scener som aldri ble spilt inn, inneholder hvert av manusene en prolog og en epilog som gir mer kontekst til handlingen i serien (det som kanskje ville være mest interessant for fandommen er epilogen til sesong 4 som finner sted høsten 2018, altså etter at selve serien har blitt avsluttet) eller noen sekvenser i sesong 2 og 3 som avslører flere detaljer henholdsvis om vennskapet mellom Even og Isak og Nooras vanskelige London-opphold.

Siden de norske originalbøkene ble utgitt med tanke på en målgruppe som kjenner serien godt, som en slags "gave" til SKAM-fandommen, ville det kanskje være logisk å konkludere med at alle eventuelle oversettelser av "råmanusene" til andre språk også ville være rettet mot fangrupper i utlandet. Om man tar dette som utgangspunkt for videre refleksjon, bør man også stille seg et spørsmål: Hva slags utfordringer må man ta hensyn til når man oversetter bøker basert på en serie som ikke er offisielt tilgjengelig for publikum i mållandet, men som likevel har en forholdsvis stor og godt integrert fandom?

\section{Aktør-nettverksteori og skjønnlitterær oversettelse}

I sin berømte tekst “Translation as a decision process" (1967) beskriver den tsjekkiske forskeren Jiří Levý oversettelsesprosessen som et slags spill, hvor oversetteren må ta en avgjørelse ved å velge ett av flere tilgjengelige alternativer, for å kunne "gå videre" der han eller hun blir konfrontert med flere situasjoner der han eller hun må ta avgjørelser. Selv om denne analogien er veldig treffende, må man - når man tar i betraktning de pragmatiske aspektene ved yrket til skjønnlitterære oversettere - nevne ett tilleggsaspekt Levý ikke konsentrerer seg om i sin artikkel, nemlig det at dette spillet aldri spilles alene. I sitt arbeid må oversetteren ta hensyn til et sammensatt nettverk av forskjellige menneskelige og ikke-menneskelige aktører, som for eksempel forlaget, forfatteren, de potensielle leserne, markedet osv.

For å prøve å finne svar på spørsmålet om hvorvidt og hvordan disse "tilleggsspillerne" eller "støttespillerne" påvirker oversetterens avgjørelser, kan man ta utgangspunkt i aktør-nettverksteori (ANT), et teoretisk og metodologisk konsept som opprinnelig stammer fra samfunnsvitenskapen. Om man skulle referere grunntanken bak ANT veldig kort og enkelt, kunne man si at det er en teori som går ut fra at samfunnet består av nettverk som dannes av forskjellige elementer (aktører) som påvirker hele nettverket og samtidig blir stadig påvirket av hele strukturen selv. "Poenget i ANT er å beskrive det som setter mennesker i stand til å handle, alle de hjelpemidler, allianser og mekanismer som 
benyttes, samt alle de maktspill som utøves, uten at bestemte aktører i utgangspunktet blir ansett for å være viktigere enn andre”, forklarer Trine Magnus (7).

Selv om konseptet, utviklet på 1980-tallet av bl.a. Michel Callon (1986) og Bruno Latour (1987), opprinnelig skulle brukes til å utforske "hvordan teknologi og vitenskap får samfunnsmessig betydning” (ibid.) og den siterte artikkelen til Magnus handler om diskursen rundt genetisk modifisert mat, brukes denne metodologiske tilnærmingen ofte i andre forskningsfelt, også innenfor humaniora og oversettelsesstudier. Ordet "oversettelse" finner man allerede i tittelen på Michel Callons berømte tekst fra 1986, "Elementer i en oversettelsessosiologi: kamskjell, fiskere og forskere". ${ }^{5}$ Selv om det ikke er skjønnlitterær oversettelse Callon mener her, men heller en sammensatt, intellektuell prosess av naturens og samfunnets dekonstruksjon og gjenkonstruksjon, bestående av fire faser: problematisering (“problématisation”), plassering av interesser (“intéressement”), verving ("enrôlement") og mobilisering av allierte, har mange forskere etter ham tatt den samme teorien som utgangspunkt for refleksjon rundt "oversettelse" i skjønnlitterær forstand, dvs. det å overføre en tekst fra ett språk til et annet og fra én kultur til en annen.

Ett av eksemplene på vitenskapelige tekster hvor ANT brukes som utgangspunkt for refleksjon rundt oversetterens plass i oversettelsesprosessen, er artikkelen "Collaborative Translation" av Joanna Trzeciak Huss, publisert i The Routledge Handbook of Literary Translation (2018). Trzeciak Huss mener at dette teoretiske grunnlaget kan virke veldig interessant når det anvendes i forbindelse med skjønnlitterær oversettelse, siden det tillater oversetteren å se bort fra den romantiske idealistiske forestillingen om en forfatter (og dermed også en oversetter) som “et ensomt geni”. I stedet bør man anta at man har å gjøre med:

agency distributed throughout a network of human and non-human actors (including networks of networks and their products), while also providing a way to individuate responsibilities for processes occurring within the network, and allowing for distinctive or hybrid roles as required by the exigencies of the case in question. (391)

Disse nettverkene, mener Trzeciak Huss, er fleksible i den forstand at forskjellige aktører kan ta på seg forskjellige roller som kan skifte over tid. Hun gir over tredve eksempler på forskjellige aktører som kan samarbeide med en skjønnlitterær oversetter innenfor ett nettverk, men konsentrerer seg særlig om interaksjoner hun mener har en spesielt stor betydning, for eksempel oversetter-medoversetter, oversetter-forfatter, oversetter-redaktør osv.

I det følgende skal jeg beskrive noen elementer av nettverket den polske oversetteren til Julie Andems SKAM-manuser var nødt til å ta hensyn til. De to viktigste aktørene som spilte en stor rolle i SKAM-nettverket under oversettelsesprosessen, var etter min mening selve serien SKAM og dens polske fandom. Det som også kan virke interessant i dette tilfellet er at forfatteren, som ofte engasjerer seg aktivt i oversettelsesprosessene der moderne litteratur er kildespråket, ${ }^{6}$ var i dette tilfellet kun "synlig" gjennom de trykte

\footnotetext{
Norsk oversettelse 2017.

6 Enten ved å ta direkte kontakt med en oversetter eller en gruppe oversettere, forberede "instrukser" og "internasjonaliserte" versjoner av manuset eller å svare på spørsmålene oversetteren har (se f.eks. Drozdowska og Podlaska 2019).
} 
kommentarene i kildeteksten. Julie Andems "meta-tilstedeværelse" i prosessen hadde dermed ikke noen aktiv påvirkning på valgene oversetteren tok. Oversetteren hadde heller ikke noen tilgang til supplerende kilder eller ressurser og dreiebøkene hun arbeidet med utgjorde en på en måte "uferdig", "uredigert" tekst. Det mest interessante trekket ved nettverket som oppstod under denne oversettelsesprosessen, var likevel multimedialitet, dvs. det faktum at oversetteren, i stedet for bare å konsentrere seg om teksten, måtte ta hensyn til andre medier, f.eks. internett, film osv. Dette i sin tur hadde en betydelig påvirkning på avgjørelsene som måtte tas i hele "oversettelsesspillet".

\section{Oversetteren i et multimedialt nettverk. SKAMs kompliserte tilfelle}

For å gjøre analysen min mer oversiktlig, har jeg bestemt meg for å dele den inn i tre tematiske sekvenser, der hver av dem er forbundet med en gruppe utfordringer som oppstår i konfrontasjon med en bestemt gruppe aktører innenfor nettverket. Den første gjelder utfordringer knyttet til aktører som det polske forlaget med sin redaksjons- og markedsavdeling, sosiale medier eller andre (potensielt lignende) titler på det polske markedet). Den andre delen av analysen tar for seg utfordringer knyttet til en gruppe ikke-menneskelige, multimediale aktører som til sammen kan betegnes som "serien SKAM", sammen med den polske fandommen, dvs. oversettelsens potensielle målgruppe. Den tredje og siste sekvensen er knyttet til utfordringene forbundet med - kanskje den viktigste - ikke-menneskelige "aktøren" i hele prosessen: de originale dreiebøkene, kjennetegnet av manglende redigeringsprosess og forfatterens "meta-tilstedeværelse" som manifesterer seg gjennom teksten. Utfordringer presentert i hver av kategoriene krever at oversetteren inntar nye roller eller anvender løsninger tett knyttet til aktørene og deres trekk, erfaringer, forventninger og behov.

\section{Forlag, marked og sosiale medier - oversetter som kulturformidler og -guide}

Som nevnt ovenfor ble rettighetene til den polske utgivelsen av SKAM-bøkene kjøpt av forlaget Rebis. Det er et mellomstort polsk forlag som ble grunnlagt i 1990, med hovedkontor i Poznań. Forlaget gir ut både skjønnlitteratur (kvalitetslitteratur og populærlitteratur, inkludert sjangre som grøsser, science-fiction, fantasy osv.) og sakprosa. Rebis har i tillegg meget godt rykte blant skjønnlitterære oversettere og fikk i 2019 prisen "Lew Hieronima" ["Hieronims løve"] som deles ut av Stowarzyszenie Tłumaczy Literatury [Den polske forening for skjønnlitterære oversettere] til forlag som utmerker seg i sin behandling av oversettere under samarbeidsprosessen.

I sin første e-post til SKAM-bøkenes oversetter, datert 14. november 2018, spør forlagsredaktøren om oversetteren er interessert i å ta oppdraget som han beskriver som "oversettelse av en boksyklus på fire bind, basert på en filmserie". Siden forlagsredaktøren (helt tilfeldigvis) valgte en oversetter som selv kjente SKAM ganske godt, var oversetteren i stand til å forklare i den videre korrespondansen at i dette tilfellet er det ikke snakk om "bøker basert på en filmserie", men heller om dreiebøker som utgjorde et slags 
utgangspunkt for serien. Dette viste seg å være noe verken forlagets redaktør eller markedsavdeling var helt klar over. Det var først etter at rettighetene til bokserien allerede var kjøpt inn, at de forsto hvor utfordrende prosjektet kunne være rent markedsmessig: det var snakk om fire bøker - "uferdige" manuser til en serie man ikke engang kan se offisielt i Polen. Her var det oversetteren som måtte forklare hva SKAM er og hva formatet går ut på. I en av samtalene mellom oversetteren og forlagsredaktøren i forbindelse med prosjektet spurte den sistnevnte "hvor på TV finner man denne serien". Da han ble informert om at man ikke kan finne SKAM på TV i det hele tatt, og at i Polen finner man serien ikke engang på "lovlig" internett, begynte han å lure på "hvem skal da kjøpe disse bøkene”. Svaret på dette spørsmålet virket ganske enkelt - siden det er seriens fandom som originalmanusene rettes mot, bør det polske forlaget markedsføre manusenes oversettelse først og fremst for fan-gruppene også på dette markedet. Som tidligere nevnt er det snakk om en gruppe på minst noen titalls tusen mennesker (i hvert fall ifølge tallene på Facebook).

Til tross for dette forsøkte markedsavdelingen hos Rebis å markedsføre SKAM-bøkene for andre grupper av potensielle lesere. Bind to av manusene (publisert på polsk i juli 2019) ble utgitt med et slags smalt smussomslag med en reklame ${ }^{7}$ som inneholder et bilde av forsiden til den polske utgivelsen av Jay Ashers bok Thirteen Reasons Why og teksten: "SKAM - boken for Thirteen Reasons Why sine fans". Boken som nevnes i reklamen ble filmatisert, og serien som ble utviklet av Brian Yorkey, har vært tilgjengelig på Netflix siden 2017. Her er det altså også snakk om en bok som utgjorde et utgangspunkt for en serie, men omtrent det eneste SKAM og 13 Reasons Why har til felles, er at de handler om tenåringer som går på videregående skole. Ellers er alt forskjellig: formatet, konseptet og kanskje først og fremst tematikken. 13 Reasons Why handler om en elev på videregående skole som begår selvmord etter at hun ble voldtatt og mobbet. Serien bygger på mye alvorligere og dystrere emner enn $S K A M,{ }^{9}$ og derfor kan denne markedsføringsstrategien antas å ikke være særlig vellykket. I en e-post-korrespondanse med oversetteren opplyser forlagsredaktøren likevel at "det med 13 Reasons" definitivt er et godt grep, ifølge markedsavdelingen på Rebis.

Polske forlag gjør ikke salgstallene tilgjengelige for publikum, og derfor er det vanskelig å si om markedsføringsstrategiene nevnt ovenfor viste seg å være vellykkete, men det som kan virke interessant i denne sammenhengen, er at oversetteren tok på seg en ekstra rolle som en slags kulturformidler i denne prosessen. Forlaget hadde opprinnelig problemer med valg av markedsføringsstrategien siden det ikke hadde nok kunnskap om produktet som skulle selges og den eventuelle målgruppen. Oversetteren fungerte dermed som en slags konsulent og hadde påvirkning på avgjørelser som vanligvis ikke faller innenfor en oversetters kompetanseområde.

Som man kan se på Rebis' Instagam-profil, der reklamen for dette bindet ble lagt ut: Instagram-reklame publisert 15. juli 2019. https://www.instagram.com/p/Bz7bF0Jo9AD/.

Alle de polskspråklige sitatene, med mindre annet er oppgitt, gjengis i min oversettelse - KD.

Selv om den norske serien også tematiserer seksuelt misbruk i en av sesongene (sesong 2 der Noora blir fotografert naken av Williams bror). 


\section{Multimedialitet og fandommen - oversetter som "fansubens" utfordrer}

Selv om man ikke har mulighet til å se $S K A M$ "offisielt" i Polen, er serien tilgjengelig på en gratis streamingsplattform, cda.pl. Som sagt kan man finne lenker til alle episodene på en av fandom-gruppene på Facebook. Serien er tilgjengelig på polsk, dvs. med polsk teksting laget av seriens fans (såkalt "fansubbing"). Jennifer Dugan og Anne Dahl har viet en hel artikkel til fan-oversettelser av SKAM. De argumenterer for at fenomenet begynte med den norske fandommen, som en reaksjon på at serien ble gjort utilgjengelig for ikke-norske IP-adresser: "In reaction, fans provided translations in the comments section on the official site, as well as subtitling and sharing episodes for their non-Norwegianspeaking peers elsewhere." (8). Med "translation" mener Dugan og Dahl oversettelse til engelsk som i sin tur utgjorde et utgangspunkt for eventuelle oversettelser til andre språk.

Det ville være mulig å analysere om oversettelsene av SKAM som er tilgjengelige på cda.pl ble laget via engelsk, men en slik undersøkelse har ikke blitt gjennomført ennå. Man kan i hvert fall fastslå at dette godt kan være tilfelle. Hver av episodene tilgjengelige på den polske streamingsplattformen ${ }^{10} \mathrm{er}$ markert med oversetterens pseudonym (vanligvis et twitter-navn) og man kan se at det var forskjellige personer involvert i oversettelsesprosessen. Kvaliteten på de polske undertekstene er også varierende. I noen episoder er det snakk om ganske gode oversettelser, i andre kan de være mangelfulle (det finnes sekvenser som ikke er oversatt) ${ }^{11}$, inneholde feil (av forskjellig type og alvorlighetsgrad) ${ }^{12}$ eller være så pass mislykket at det ikke er mulig å forstå hva som skjer på skjermen. ${ }^{13}$

Uansett situasjonen som er beskrevet ovenfor må man slå fast at oversetteren til $S K A M$-bøkene i stor grad ble nødt til å arbeide med et materiale som allerede hadde blitt oversatt, lage en oversettelse som skulle "overstyre" en versjon som fandommen kjenner og som er laget av denne fandommen. Dette kunne potensielt utgjøre en stor utfordring, spesielt med tanke på mottakelsen av den polske versjonen av manusene. De oversatte $S K A M$-bøkene hadde derimot to utvilsomme fordeler som selv den mest konservative fandommen ikke kunne se bort fra: først og fremst var de oversatt direkte fra originalspråket. For det andre inneholdt de sekvenser som ikke finnes i selve serien og

10 Spørsmålet om de polske streamingsplattformene, f.eks. cda.pl strider mot loven er vanskelige å svare på. Ifølge den polske åndsverkloven, er det ikke tillatt å lagre, reprodusere og distribuere et innhold man ikke har rettigheter til. Det er derimot ikke ulovlig å se på innholdet som legges ut online i form av streamingtjenester. Eierne av cda.pl hevder at nettstedet deres er et sosialt medium der det kun er brukere som legger ut materiale og derfor er det eventuelt bestemte personer som benytter seg av tjenesten som bryter loven, ikke plattformen (se f.eks. Czubkowska 2015). Man kan konkludere med å si at de polske "uoffisielle" oversettelsene av SKAM eksisterer i en slags gråsone den polske åndsverkloven ikke har utarbeidet verktøy til å kontrollere ennå.

11 Særlig rim, regler, ordspill osv.

12 Det kan være alt fra stilfeil (f.eks. der det norske begrepet "vorspiel" blir oversatt som "zaprawa", et ord som riktignok betyr omtrent det samme som den norske originalen, men brukes av en annen aldersgruppe et SKAMs karakterer. Dreiebøkenes oversetter har derimot foreslått ordene "after" eller "afterek") til feil som forvrenger originalens betydning. For eksempel: i episode 1 av sesong 3 sier Jonas at han "gikk ned på" en jente, noe som i den polske fan-oversettelsen ble til "spuściłem się na nią" et uttrykk som betyr ejakulering heller enn oralsex. Dreiebøkenes oversetter brukte i dette tilfellet begrepet "zrobiłem jej minetkę", som tydelig antyder cunnilingus.

13 Kanskje særlig i sesong 4, der Sana gjennomfører et ganske komplisert "sosialt attentat" på en av venninnene ved bruk av Instagram-poster. 
som dermed ikke var oversatt av fansen. I et intervju i bokmagasinet Książi (Suchecka 2019) understreker den polske oversetteren at hun har mye respekt for de eksisterende oversettelsene, men at hun noen ganger måtte ta andre valg enn fans-oversetterne, først og fremst fordi hun la mer vekt på nøyaktighet. Hun nevner også elementer som ikke var oversatt av fansen: rim, vitser eller ordspill (24).

Bokens oversetter måtte da først og fremst ta hensyn til slike aktører innenfor nettverket som selve serien, fandommen og den eksisterende oversettelsen. Dette krevde en helt annerledes form for arbeid enn det man ville gjøre om boken allerede var blitt oversatt. Et multimedialt nettverk krevde også multimediale strategier, f.eks. det at oversetteren faktisk var nødt til å se hele serien med de polske og ofte mangelfulle undertekstene, bare for å være klar over hva det var hun skulle "overstyre".

\section{Den usedvanlige originalteksten - oversetter som språkelev og autentisitetens vokter}

En hel egen kategori av utfordringer forbundet med oversettelsen av SKAM-manusene til polsk stammet fra bøkenes unike form som allerede har blitt omtalt i denne teksten. Manusenes "uferdighet", sammen med det spesifikke språket de ble skrevet på, krevde en rekke løsninger og strategier som man vanligvis ikke engang tenker på i løpet av en mer tradisjonell oversettelsesprosess. Siden målgruppen for den polske boken først og fremst var seriens fans, ble det avgjort at kvalitetene oversetteren og forlaget skulle satse på, var autentisitet og troverdighet, dvs. at fandommen måtte få et produkt som opplevdes "ekte" og som var framstilt av personer som kjente serien og hadde en god forståelse av den. Med utgangspunkt i disse mål ble det tatt en rekke tekniske avgjørelser forbundet med de polske utgavene av bøkene.

Først og fremst ble det bestemt at for- og baksatsillustrasjonene med Julie Andems tankekart ikke skulle oversettes, men trykkes slik de ble trykt i originalutgavene, med serieskaperens norske håndskrevne notater og tegninger. Her avgjorde det polske forlaget at autentisiteten var viktigere enn det at leserne faktisk skulle forstå de enkelte ordene notert av Andem. For det andre diskuterte forlaget og oversetteren om et forord eller et etterord med forklaringer rundt bøkenes usedvanlige form skulle inkluderes i manusene. Et slikt nytt element ville gjøre det lettere for leserne å orientere seg i dreiebøkene, men det ble endelig bestemt at siden det ikke finnes et forord eller etterord i de norske originalene, skulle en slik ny sekvens heller ikke introduseres i den polske oversettelsen. Rebis har likevel bestemt seg for å avvike fra originalmanusene på et annet plan, dvs. ved å rette opp alle trykk- og skrivefeil i egennavn i den norske teksten (av typen "Stella Mccarty" som nevnes ovenfor), for å unngå anklager om at disse unøyaktighetene er slurvefeil fra det polske forlagets eller oversetterens side. I dette tilfellet ble autentisiteten ofret for et overordnet, rent pragmatisk mål.

Kanskje var den største utfordringen knyttet til ungdomsspråket i bøkene. Julie Andem (født 1982) nevner selv (Suchecka 23) at hun brukte mye tid på å reise rundt i Norge og snakke med ungdommer, for å lære seg hvordan de tenker og snakker. I tillegg ble tenåringsskuespillerne i SKAM ofte bedt om å improvisere (noe som også ofte kommenteres i manusene). Derfor er det norske ungdomsspråket i serien (og dreiebøkene) så troverdig, og det var viktig for det polske forlaget og oversetteren å bevare denne troverdigheten. 
Siden den polske oversetteren er omtrent like gammel som seriens skaper, kunne det være snakk om en slags parallell erfaring av forsøket på å gjengi “det virkelige” ungdomsspråket på polsk og på norsk. Oversetteren valgte en strategi inspirert av det Andem selv gjorde og konsulterte sin polske tekst med en gruppe 16 år gamle kvinnelige elever på videregående skole. Disse elevene hadde aldri sett SKAM selv, men var veldig bestemte, kritiske og hjelpsomme når det gjaldt verifisering av ungdomsspråkets autentisitet. Denne prosessen avslørte også hvor efemer noen ord og uttrykk er i dette språkregisteret, og hvor fort de mister sin aktualitet. Under konsultasjonene spurte oversetteren om det ville være naturlig for en sekstenåring å si at noe skjer "na fejsie" ["på face”, dvs. på Facebook]. Konsulentene svarte at det ikke ville være naturlig siden "ingen bruker Facebook lenger" (de påsto at de selv kun bruker sosiale medier som Instagram eller Snapchat). Dette eksemplet kan også være et godt utgangspunkt for en refleksjon rundt hvor kortvarig aktualiteten av ungdomskultur - og dermed også SKAM ${ }^{14}$ - kan være.

\section{Konklusjoner - oversetteren som nettverkskoordinator}

I denne case-studien har det blitt presentert hvor forskjellige roller en oversetter kan ha i et nettverk som etableres i forbindelse med oversettelsesprosessen til en multimedial tekst. Selv om selve fenomenet multimedialitet i oversettelse ikke er noe nytt, ville jeg argumentere at prosessen beskrevet ovenfor var - i hvert fall i noen av sine aspekter - enestående. I SKAM-bøkenes tilfelle har oversetteren også blitt en slags kulturformidler eller -mekler, guide, utfordrer og vokter. Denne sammensatte "hybride" rollen hadde som oppgave å forklare originaltekstens særegenhet overfor forlaget, og oversetteren ble dermed involvert i viktige avgjørelser om for eksempel lesernes målgruppe eller markedsføringsstrategi. Tekstens unike form og status krevde også at en rekke tilleggsaktører (både menneskelige og ikke-menneskelige) ble involvert i nettverket. Som eksempler kan det nevnes originalserien (og dens tidligere oversettelser), fandommen, konsulenter fra den potensielle målgruppen osv. Man kan trekke den konklusjonen at oversetteren, som den eneste av nettverkets menneskelige aktører som hadde oversikt over de andre elementene i dette systemet og hvordan de fungerer, påtok seg en rolle som en slags nettverkskoordinator, og hadde dermed en mye større påvirkning på det endelige produktet enn en oversetter vanligvis har i tradisjonelle prosesser.

Man kan konkludere med at den pågående globaliseringsprosessen og flere intermediale oversettelsesprosjekter antakelig vil føre til opprettelse av flere slike nettverk og dermed til at skjønnlitterære oversetteres kompetanseområde innenfor disse nettverkene gradvis utvides og at deres status på markedet økes med tiden. En slik utvikling kan også potensielt føre til framtidsvisjoner der profesjonelle skjønnlitterære oversettere etter hvert blir erstattet av grupper av anonyme online-oversettere støttet av programmer og

14 Avslutningsvis kan det nevnes at - til tross for SKAMs store popularitet på streamingsplattformene og Rebis' prosjekt med bokutgivelsene - er det foreløpig (per juni 2020) ikke snakk om en polsk versjon av serien eller sending av den norske versjonen på noen "offisielle" kanaler, med en "offisiell" polsk oversettelse. 
verktøy til maskinoversettelse, men denne dystopien er etter min mening lite sannsynlig. Det er riktignok uunnværlig at den tradisjonelle oversettelsesprosessen vil undergå forandringer med tiden, men den menneskelige, profesjonelle oversetteren forblir den eneste som har tilstrekkelig språk-, kultur- samt teknisk kompetanse til å styre og koordinere nettverket. Det er altså mest sannsynlig at skjønnlitterære oversettere vil "overleve", men vilkåret for deres effektive virkning i nettverket er å åpne seg mot behovet for å skaffe nye kompetanser og samarbeide med nye aktører.

\section{LITTERATUR}

\section{Dreiebøker}

Andem, Julie. SKAM. Sesong 1: Eva. Oslo: Armada Forlag, 2018.

Andem, Julie. SKAM. Sesong 2: Noora. Oslo: Armada Forlag, 2018.

Andem, Julie. SKAM. Sesong 3: Isak. Oslo: Armada Forlag, 2018.

Andem, Julie. SKAM. Sesong 4: Sana. Oslo: Armada Forlag, 2018.

\section{Serier}

13 Reasons Why. Utviklet av: Brian Yorkey. July Moonhead Productions mfl., 2017-.

DRUCK. Regi: Pola Beck mfl. Bantry Bay Productions, 2018-.

SKAM. Regi: Julie Andem. Norsk rikskringkasting, 2015-2017. Nettbasert serie tilgjengelig for norske IPadresser på http://skam.p3.no/ [tilgang 21. 02. 2020].

Skam Austin. Regi: Julie Andem og Phillip Bartell. XIX Entertainment, Julie Andem Stories, Shiny Unicorn, 2018-.

Skam España. Regi: Begoña Álvarez og José Ramón Ayerra. Zeppelin TV, 2018-.

Skam France. Regi: David Hourregue. Gétévé Productions, France Télévisions, 2018-.

Skam Italia. Regi: Ludovico Bessegato og Ludovico Di Martino. TIMvision, Cross Productions, 2018-.

Skam NL. Regi: Bobbie Koek mfl. NTR, Beta Film, 2018-2019.

WtFOCK. Regi: Cecilia Verheyden og Tom Goris. beta Film, 2018-.

\section{Trykte kilder}

Asher, Jay. 13 powodów. Poznań: Rebis, 2017.

Callon, Michel. "Elementer i en oversettelsessosiologi: kamskjell, fiskere og forskere". Teknovitenskapelige kulturer. Red. K. Asdal mfl. Valdres, Spartacus forlag AS, 2017. 91-124.

Callon, Michel. "Some elements of sociology od translation domestication of the scallops and the fishermen of Saint Brieuc Bay". Power, action and belief: A new sociology of knowledge? Red. J. Law. London, Routledge 1986. 196-233.

Chacińska, Maja. W służbie ludu i inżynierii społecznej. Gdańsk: Wydawnictwo Uniwersytetu Gdańskiego 2018.

Drozdowska, Karolina og Magdalena Podlaska. Przekład współczesnej prozy nordyckiej to nie problem, to wyzwanie! Norwegia i Finlandia. Gdańsk: Wydawnictwo Uniwersytetu Gdańskiego 2019.

Dugan, Jennifer og Anne Dahl. "Fan translations of SKAM: Challenging Anglo linguistic and popular cultural hegemony in a transnational fandom”. Scandinavian Studies in Language, 10(2). 2019: 6-29.

Latour, Bruno. Science in action. Milton Keynes: Open University Press 1987.

Levý, Jiří. "Translation as a decision process". To Honor Roman Jakobson: Essays on the occasion of his seventieth birthday, vol. 2. Haag: Mouton 1967, 1171-1182.

Magnus, Trine. Kan Aktør-nettverk-teori vere et nyttig perspektiv for 'genmat' diskursen? Norsk senter for bygdeforskning, Paper no 4-06, 2006.

Philipsen, Heidi og Tobias Hochscherf. Beyond the Bridge: Contemporary Danish Television Drama. London, I.B. Tauris 2016.

Suchecka, Justyna. “Skam znaczy wstyd”. Najlepsze Książki dla dzieci i dorostych (Książki. Magazyn do czytania), nr. 3 (2019): 22-25. 
Sundet, Vilde Schanke. "From 'secret' online teen drama to international cult phenomenon: The global expansion of SKAM and its public service mission". Critical Studies in Television. 2019. https://doi .org/10.1177/1749602019879856.

Trzeciak Huss, Joanna. "Collaborative translation". The Routledge Handbook of Literary Translation. Red. K. Washbourne og B. Van Wyke. London: Routledge, 2018. 389-405.

\section{Internettkilder}

Armada. https://strawberrypublishing.no/armada/ [tilgang 21. 02. 2020].

Minana, Emil. "Guide: Sådan kan du alligevel se SKAM uden for Norge”. Se og hør 13. januar 2017. Tilgjengelig online: https://www.seoghoer.dk/nyheder/saadan-kan-du-alligevel-se-skam-uden-norge [tilgang 21. 02. 2020].

NTB. "Ikke lenger mulig å se Skam i utlandet". Aftenposten 31. januar 2017. Tilgjengelig online: https://www .aftenposten.no/kultur/i/LR5dQ/ikke-lenger-mulig-aa-se-skam-i-utlandet [tilgang 21. 02. 2020].

Pahle, Christopher. "Hva skal vi med alle disse "Skam"-versjonene?". Dagbladet 3. mai 2018. Tilgjengelig online: https://www.dagbladet.no/kultur/hva-skal-vi-med-alle-disse-skam-versjonene/69767355 [tilgang 21. 02. 2020].

Rebis. https://www.rebis.com.pl/ [tilgang 28. 02. 2020].

Stowarzyszenie Tłumaczy Literatury. "Lew Hieronima dla Domu Wydawniczego Rebis". http://stl.org.pl /lew-hieronima-dla-domu-wydawniczego-rebis/ [tilgang 28. 02. 2020].

\section{Audiovisuelle kilder}

Andem, Julie og Mari Magnus. "SKAM Case". MediaMorfosis, Buenos Aires. September 2017. https://www .youtube.com/watch? $\mathrm{v}=\mathrm{i} 6 \mathrm{gCzxrtIPs} \& \mathrm{t}=429$ s [tilgang 21. 02. 2020].

Cda.pl. Streamingsplattform [tilgang 21. 02. 2020].

Coursaud, Jean Baptiste. Intervju: "Frankrike elsker Fosse og Lygre”. NRK bok 28.03.2018. https://radio.nrk.no /podkast/bok_i_p2/nrkno-poddkast-17524-134019-27032018160600 [tilgang 21. 02. 2020].

Czubkowska, Sylwia. "Jak by na nich nie spojrzeć - legalni. Serwis CDA.pl i kulisy działania polskiego YouTube". Dziennik.pl 01. 11. 2015. https://technologia.dziennik.pl/internet/artykuly/504361,cdapl-skad-sie -wzial-serwis-z-filmami-i-grami-cdapl.html [tilgang 08. 06. 2020].

Rettberg, Jill Walker. "A Narrative Analysis of the use of Social Media in SKAM". ELO, Porto. 20. juli 2017. https://www.researchgate.net/publication/320498619_A_Narrative_Analysis_of_the_Use_of_Social _Media_in_SKAM [tilgang 21.02.2020].

\section{Bachelor- og masteroppgaver}

Berbeć, Magda. "Er det plass for feminisme i populærkultur? Fremstilling av kvinner i den norske ungdomsserien SKAM”. Masteroppgave. Universitetet i Gdańsk, 2018.

Ćwikowska, Paulina. "Gjentolkning av norsk nasjonal identitet i NRKs tv-serie SKAM". Bacheloroppgave. Universitetet i Gdańsk, 2017.

Drzycimska, Zofia. "En komparativ analyse av sosiokulturelle forskjeller på tenåringers liv basert på den norske TV-serien Skam og den amerikanske nyinnspillingen SKAM Austin”. Masteroppgave. Universitetet i Gdańsk, 2019.

Kaczmarek, Marta. "Sosiale spørsmål i Skam - fremstilling og mottakelse". Masteroppgave, Universitetet i Gdańsk, 2017.

Turzyńska, Alicja. "Reaktionen på den norske tv-serien Skam - analyse af de utvalgte artikler fra Berlingske". Bacheloroppgave. Universitetet i Gdańsk, 2017.

Włodarczyk, Weronika. "Diskursanalyse av religion i tv-serien SKAM". Bacheloroppgave. Universitetet i Gdańsk, 2018.

\section{Sosiale medier, e-post-korrespondanse, upublisert materiale}

Dom Wydawniczy Rebis. Instagram-reklame publisert 15. juli 2019. https://www.instagram.com/p/Bz7b F0Jo9AD/ [tilgang 20. 02. 2020].

Konsultasjoner mellom den polske oversetteren og en gruppe potensielle lesere - videregående skoleelever. Mars 2019.

Laskowicz, Paweł. "propozycja translatorska Rebis”. E-post til K. Drozdowska. 14. november 2018. 
Laskowicz, Paweł. “RE: reklama na facebooku”. E-post til K. Drozdowska. 15. april 2019.

SKAM Polska. Facebookprofiler og -grupper. https://www.facebook.com/search/top/?q=skam\%20polska \&epa=SEARCH_BOX [tilgang 21.02.2020].

Telefonsamtaler mellom forlaget Rebis og SKAM-bøkenes oversetter, november 2019-mars 2020.

Karolina Drozdowska

University of Gdansk

karolina.drozdowska@ug.edu.pl 